\title{
PERENCANAAN PENJADUALAN KANTOR GEDUNG PT GRESIK JASATAMA DENGAN METODE FUZZY LOGIC APPLICATION FOR SCHEDULING
}

\author{
Arif Miftakul Huda \\ CV. Mukti Jaya Abadi \\ Email : teknik.industriunmuh@gmail.com
}

ABSTRAK

\begin{abstract}
CV. Mukti Jaya Abadi adalah perusahaan dibidang General Contraktor and Suplier, selama ini perusahaan dalam menjadualkan proyek didasari oleh analisa kepala proyek dan estimator proyek, hasilnya terdapat ketidakpastian terhadap waktu penyeleseian proyek.Oleh karena itu dibutuhkan pendekatan yang tepat untuk menentukan waktu proyek, dalam hal ini metode fuzzy mampu memberikan penyelesaian yang baik untuk hal-hal yang bersifat tidak pasti. Fuzzy Logic Aplication for Scheduling (FLASH) merupakan metode yang tepat untuk mengakomodasi ketidak pastian. FLASH tidak mensyaratkan data statistic tetapi hanya pengamatan secara kualitatif.Hasil akhir yang diperoleh menunjukan proyek dapat diseleseikan kisaran 119 hari sampai 221 hari dengan waktu paling mungkin 163 hari dengan nilai defuzzyfikasi 170 hari.
\end{abstract}

\section{Kata kunci:Metode penjadualan FLASH, Posibilitas,Set samar}

\section{PENDAHULUAN}

Pembangunan gedung kantor PT. Gresik Jasatama merupakan salah satu respon dari PT. Gresik Jasatama untuk menyiapkan diri sebagai salah satu perusahaan jasa kepelabuhan diwilayah Gresik. Proyek ini merupakan proyek yang akan diperebutkan oleh beberapa kontraktor, sehingga penawaran yang tepat baik berupa biaya, kualitas dan waktu akan menjadi pemenangnya. Proyek pada umumnya memiliki batas waktu (deadline). Berkaitan dengan masalah ini maka keberhasilan pelaksanaan proyek tepat pada waktunya merupakan tujuan yang paling penting baik pemilik proyek maupun kontraktor. Perencanaan waktu atau jadwal proyek meliputi langkah-langkah yang bertujuan agar proyek dapat diseleseikan sesuai dengan sasaran waktu yang ditetapkan. Perencanaan waktu memberikan masukan kepada perencanaan sumber daya agar sumber daya tersebut siap pada waktu yang diperlukan, kemudian baru perencanaan biaya bisa dilakukan. Dari perencanaan ini diharapkan akan menghasilkan penawaran yang tepat.

Pada penelitian ini Peneliti melakukan penelitian pada CV. Mukti Jaya Abadi, merupakan kontraktor yang akan merencanakan penjadualan proyek tersebut. CV. Mukti Jaya Abadi merupakan salah satu perusahaan yang bergerak dibidang General Contractor and Suplier. Proyek yang didapat perusahaan berasal dari tender yang dimenangkan perusahaan maupun konsumen yang datang secara 
langsung.

Pada kenyataannya CV. Mukti Jaya Abadi dalam menyelesaikan aktifitas suatu proyek bisa lebih cepat bahkan juga bisa lebih lambat dari rencana yang sudah ditentukan. Berikut adalah waktu penyeleseian proyek yang memiliki kegiatan - kegiatan yang sejenis dengan kegiatan proyek pembangunan gedung kantor PT. Gresik Jasatama yang dilaksanakan oleh CV. Mukti Jaya Abadi:

\begin{tabular}{|c|c|c|c|}
\hline Samp Prọid & Wabthryguditathan & That p pelassum & Junbuleles \\
\hline 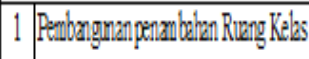 & 60 & $\theta$ & 5 keles 1 bantit \\
\hline 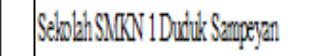 & & & \\
\hline 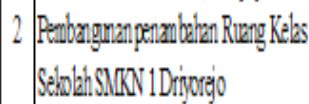 & 60 & 55 & $2 \mathrm{keks} 2 \mathrm{kantzi}$ \\
\hline 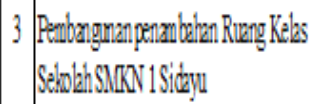 & 60 & 67 & $2 \mathrm{kelas} 2 \mathrm{kantzi}$ \\
\hline
\end{tabular}

Dari tabel diatas terlihat adanya ketidakpastian waktu penyelesaian proyek., hal ini disebabkan karena material terlambat didatangkan dan faktor cuaca yaitu hujan. Dalam kasus diatas CV. Mukti Jaya Abadi dalam penentuan waktu penyelesaian proyek yang dijanjikan pada konsumen didasari oleh analisa dari kepala proyek dan estimator proyek. Oleh karena itu dibutuhkan pendekatan yang tepat untuk menentukan waktu proyek. Dalam hal ini metode fuzzy mampu memberikan penyelesaian yang baik untuk hal-hal yang bersifat tidak pasti. Fuzzy Logic Application for sceduling (FLASH), merupakan metode penjadwalan den- gan tetap mengakomodasi ketidakpastian durasi. FLASH menggunakan terminologi posibilitas dari pada probabilitas untuk mengekspresikan ketidakpastian. Hal ini menjadikan FLASH lebih terbuka dalam hal ketidakpastian. FLASH menganalisis semua jalur untuk menghasilkan posibilitas suatu total durasi proyek yang diharapkan.

\section{Tujuan Penelitian}

Tujuan yang ingin dicapai dalam pemecahan masalah-masalah ini adalah :

1. Menentukan bentuk jaringan kerja pada proyek Pembangunan Kantor Gedung PT. Gresik Jasatama.

2. Mengetahui durasi pelaksanaan proyek Pembangunan Kantor Gedung PT. Gresik Jasatama dengan metode FLASH.

3. Mengetahui pekerjaan mana saja yang temasuk kegiatatan kritis pada proyek Pembangunan Kantor Gedung PT. Gresik Jasatama.

\section{TINJAUAN PUSTAKA}

\section{Pengertian Proyek}

Menurut Soeharto (1999) Kegiatan proyek dapat diartikan sebagai satu kegiatan sementara yang berlangsung dalam jangka waktu terbatas, dengan alokasi sumber daya tertentu dan dimaksudkan untuk menghasilkan produk atau deliverable yang kriteria mutunya telah digariskan dengan jelas. 


\section{Manajemen proyek}

Managemen proyek adalah ilmu dan seni yang berkaitan dengan memimpin dan menkoordinir sumber daya yang terdiri dari manusia dan meterial dengan menggunakan teknik pengolahan modern untuk mencapain sasaran yang telah ditentukan, yaitu lingkup, mutu, jadwal, dan biaya, serta memenuhi keinginan para stake holder.

\section{Pengertian Perencanaan Proyek}

Dalam manajemen proyek, perencanaan dan pengendalian adalah tahap yang sangat penting dalam menentukan keberhasilan proyek. Perencanaan dan pengendalian yang baik adalah paduan untuk melaksanakan pekerjaan proyek secara efektif dan efesien. Masalah akan timbul apabila terjadi ketidaksesuaian antara rencana awal dengan realisasi yang ada dalam pelaksanaan proyek, perencanaan awal berupa penyusunan (anggaran biaya, jadwal induk/waktu, penetapan spesifikasi/mutu).

Perencanaan menempati urutan pertama dari fungsi - fungsi manajemen seperti mengorganisir, memimpin, dan mengendalikan. Perencanaan adalah suatu proses yang mencoba meletakan dasar tujuan dan sasaran termasuk menyiapkan langkah langkah kegiatan beserta segala sumber daya untuk mencapai tujuan tersebut.

\section{Pengertian Penjadwalan Proyek}

Jadwal adalah Penjabaran perencanaan proyek menjadi urutan langkah langkah pelaksanaan pekerjaan yang telah dimasukkan faktor waktu untuk mencapai sasaran. Secara umum dapat dikatakan bahwa penjadwalan adalah perhitungan pengalokasian waktu yang tersedia kepada pelaksanaan masing masing bagian pekerjaan atau kegiatan, dalam rangka penyelesaian proyek sedemikian rupa, sehingga tercapai hasil yang optimal, dengan mempertimbangkan keterbatasan- keterbatasan yang ada.

\section{Metode Penjadwalan Proyek.}

Pemilihan metode penjadwalan pada suatu proyek dapat dipengaruhi oleh jenis pekerjaannya apakah merupakan pekerjaan berulang atau tidak, besar atau kecilnya proyek, ataupun sifat/karakteristik dari proyek yang lain. Metode dalam penjadwalan dan pengendalian proyek saat ini mengalami perkembangan, dalam usaha meningkatkan kualitas perencanaan dan pengendalian proyek telah diperkenalkan berbagai teknik dan metode.

\section{Work Breakdown Structure (WBS)}

Kegiatan menguraikan pekerjaan proyek menjadi elemen - elemen yang lebih kecil yang secara operasional mudah dilaksanakan serta mudah diestimasi biaya dan waktu pelaksanaannya. Hasil proses hirerarkis ini disebut Work Breakdown Structure (WBS). WBS adalah peta proyek. Penggunaan WBS dapat membantu meyakinkan manajer 
proyek bahwa semua produk dan elemen pekerjaan proyek telah diidentifikasi, untuk mengintegrasikan proyek dengan organisasi saat ini, dan untuk membangun dasar pengendalian (Cilfford F. Gray, Erik W. Larson 2007 : 96).

\section{Metode Diagram Batang (Bar Graph Method)}

Yang pertama dikembangkan dalam perencanaan dan penjadwalan adalah Gantt Charts. Nama ini mengacu pada penemunya Henry L. Gantt, seorang konsultan manajemen terkenal. Apa yang diperlihatkan dalam Gantt Charts adalah hubungan antara aktivitas dan waktu pengerjaanya. Disini bisa juga dilihat aktivitas mana yang harus mulai dulu dan aktivitas mana yang menyusul. Gantt Charts dibuat menyusul selesainya WBS.

\section{Jaringan Kerja}

Network planning (Jaringan Kerja) pada prinsipnya adalah hubungan ketergantungan antara bagian-bagian pekerjaan yang digambarkan atau divisualisasikan dalam diagram network. Dengan demikian dapat dikemukakan bagian-bagian pekerjaan yang harus didahulukan, sehingga dapat dijadikan dasar untuk melakukan pekerjaan selanjutnya dan dapat dilihat pula bahwa suatu pekerjaan belum dapat dimulai apabila kegiatan sebelumnya belum selesai dikerjakan.

Simbol-simbol yang digunakan dalam menggambarkan suatu network adalah sebagai berikut : a. (anak panah/busur), mewakili sebuah kegiatan atau aktivitas yaitu tugas yang dibutuhkan oleh proyek. Kegiatan di sini didefinisikan sebagai halyang memerlukan duration (jangka waktu tertentu) dalam pemakaian sejumlah resources (sumber tenaga, peralatan, material, biaya). Kepala anak panah menunjukkan arah tiap kegiatan, yang menunjukkan bahwa suatu kegiatan dimulai pada permulaan dan berjalan maju sampai akhir dengan arahdari kiri ke kanan. Baik panjang maupun kemiringan anak panah ini sama sekali tidak mempunyai arti. Jadi, tak perlu menggunakan skala.

b. (lingkaran kecil/simpul/node), mewakili sebuah kejadian atau peristiwa atau event. Kejadian (event) didefinisikan sebagai ujung atau pertemuan dari satu atau beberapa kegiatan. Sebuah kejadian mewakili satutitik dalam waktu yang menyatakan penyelesaian beberapa kegiatan dan awal beberapa kegiatan baru. Titik awal dan akhir dari sebuah kegiatan karena itu dijabarkan dengan dua kejadian yang biasanya dikenal sebagai kejadian kepala dan ekor. Kegiatan-kegiatan yang berawal dari saat kejadian tertentutidak dapat dimulai sampai kegiatankegiatan yang berakhir pada kejadianyang sama diselesaikan. Suatu kejadian harus mendahulukan kegiatan yang keluar dari simpul/node tersebut.

c. $-ー-ー \rightarrow$ (anak panah terputus-putus), me- 
nyatakan kegiatan semu atau dummy activity. Setiap anak panah memiliki peranan ganda dalam mewakili kegiatan dan membantu untuk menunjukkan hubungan utama antara berbagaikegiatan. Dummy di sini berguna untuk membatasi mulainya kegiatan seperthalnya kegiatan biasa, panjang dan kemiringan dummy ini juga tak berarti apa-apa sehingga tidak perlu berskala. Bedanya dengan kegiatan biasa ialah bahwa kegiatan dummy tidak memakan waktu dan sumber daya, jadi waktu kegiatan sama dengan nol.

Adapun logik ketergantungan kegiatan-kegiatan itu dapat dinyatakan sebagai berikut

a. Jika kegiatan A harus diselesaikan dahulu sebelum kegiatan B dapat dimulai dan kegiatan C dimulai setelah kegiatan B selesai, maka hubungan antara kegiatan tersebut dapat di lihat pada gambar 2.4

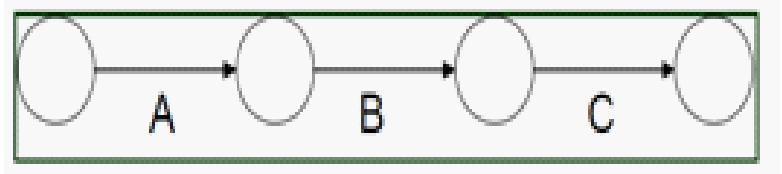

b. Jika kegiatan A dan B harus selesai sebelum kegiatan $\mathrm{C}$ dapat dimulai, maka dapat di lihat pada gambar 2.5

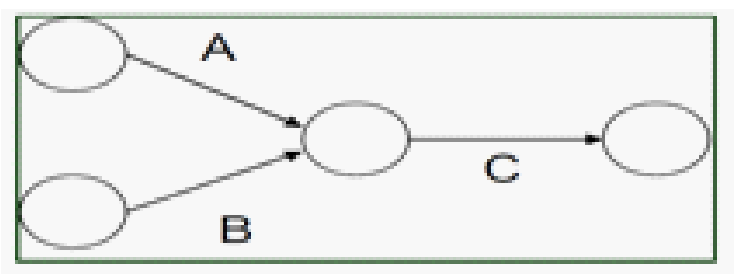

c. Jika kegiatan A dan B harus dimulai sebelum kegiatan C dan D maka dapat dilihat pada gambar 2.6

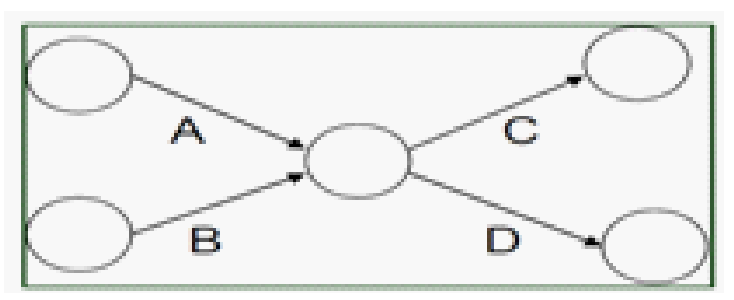

c. Jika kegiatan A dan B harus selesai sebelum kegiatan $\mathrm{C}$ dapat dimulai, tetapisudah dapat dimulai bila kegiatan B sudah selesai, maka dapat dilihat pada gambar 2.7

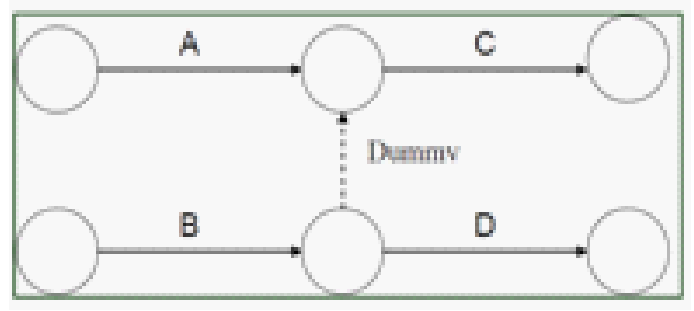

\section{Lintasan Kritis}

Heizer dan Render (2005) menjelaskan bahwa dalam dalam melakukan ananalisis jalur kritis, digunakan dua proses two-pass, terdiri atas forward pass danbackward pass. ES dan EF ditentukan selama forward pass, LS dan LF ditentukan selama backward pass. ES (earliest start) adalah waktu terdahulu suatu kegiatan dapat dimulai, dengan asumsi semua pendahulu sudah selesai. EF(earliest finish) merupakan waktu terdahulu suatu kegiatan dapat selesai. LS

(latest start) adalah waktu terakhir suatu kegiatan dapat dimulai sehingga tidakmenunda waktu penyelesaian keseluruhan proyek. LF (latest finish) 
adalah waktu terakhir suatu kegiatan dapat selesai sehingga tidak menunda waktu penyelesaian keseluruhan proyek.

$\mathrm{ES}=\mathrm{Max}\{\mathrm{EF}$ semua pendahulu langsung $\}$

$\mathrm{EF}=\mathrm{ES}+$ Waktu kegiatan

$\mathrm{LF}=\operatorname{Min}\{\mathrm{LS}$ dari seluruh kegiatan yang langsung mengikutinya\}

$\mathrm{LS}=\mathrm{LF}-$ Waktu kegiatan

Slack $=\mathrm{LS}-\mathrm{ES} \quad$ atau $\quad$ Slack $=\mathrm{LF}-\mathrm{EF}$

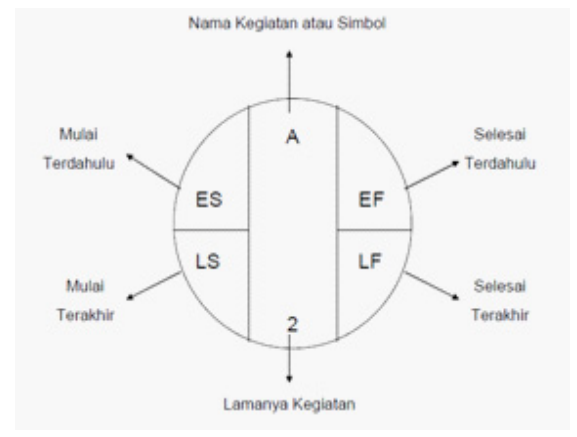

\section{Critical Path Methode ( CPM ).}

Menurut Levin dan Kirkpatrick (1972), metode Jalur Kritis (CriticalPath Method - CPM), yakni metode untuk merencanakan dan mengawasi proyek proyek merupakan sistem yang paling banyak dipergunakan diantara semua sistem lain yang memakai prinsip pembentukan jaringan. Dengan CPM, jumlah waktu yang dibutuhkan untuk menyelesaikan berbagai tahap suatu proyek dianggap diketahui dengan pasti, demikian pula hubungan antara sumber yang digunakan dan waktu yang diperlukan untuk menyelesaikan proyek. CPM adalah model manajemen proyek yang mengutamakan bi- aya sebagai objek yang dianalisis (Siswanto, 2007). CPM merupakan analisa jaringan kerja yang berusaha mengoptimalkan biaya total proyek melalui pengurangan atau percepatan waktupenyelesaian total proyek yang bersangkutan.

Dalam metode CPM (Critical Path Method Metode Jalur Kritis)dikenal dengan adanya jalur kritis, yaitu jalur yang memiliki rangkaian komponen-komponen kegiatan dengan total jumlah waktu terlama.Jalur kritis terdiri dari rangkaian kegiatan kritis, dimulai dari kegiatan pertama sampai pada kegiatan terakhir proyek (Soeharto, 1999). Lintasan kritis(Critical Path) melalui aktivitas-aktivitas yang jumlah waktu pelaksanaannya paling lama. Jadi, lintasan kritis adalah lintasan yang paling menentukan waktu penyelesaian proyek secara keseluruhan

\section{Durasi Proyek}

Durasi proyek adalah jumlah waktu yang diperlukan untuk menyelesaikan seluruh pekerjaan proyek (Maharany dan Fajarwati, 2006). Maharany dan Fajarwati (2006) menjelaskan bahwa faktor yang berpengaruh dalam menentukan durasi pekerjaan adalah volume pekerjaan, metode kerja (construction method), keadaan lapangan, serta keterampilan tenaga kerja yang melaksanakan pekerjaan proyek. 


\section{LogikaFuzzy}

Titik awal dari konsep modern mengenaike tidakpastian adalah paper yang dibuat oleh Lofti A Zadeh, dimana Zadeh memperkenalkan teori yang memiliki objek-objek dari himpunan Fuzzy yangmemiliki batasan yang tidak presisi dan keanggotan dalam himpunan Fuzzy, dan bukan dalam bentuk logika benar(true) atau salah(false), tapi dinyatakan dalam derajat(degree). Konsep seperti ini disebut dengan Fuzziness dan teorinya dinamakan Fuzzy Set Theory.

Ada beberapa alasan mengapa orang menggunakan logika Fuzzy,

antara lain:

1. Konsep dengan logika Fuzzy mudah dimengerti. Konsep matematis yang mendasari penalaran Fuzzy sangat sederhana dan mudah dimengerti.

2. Logika Fuzzy sangat fleksibel.

3. Logika Fuzzy memiliki toleransi terhadap datadata yang tidak tepat.

4. Logika Fuzzy mampu memodelkan fungsifungsi nonlinear yang sangat kompleks.

5. Logika Fuzzy dapat membangun dan mengaplikasikan pengalaman pengalaman parapakarsecara langsung tanpa harus melalui proses pelatihan.

6. Logika Fuzzy dapat bekerjasama dengan teknik- teknik kendali secara konvensional.

7. Logika Fuzzy didasarkan pada Bahasa

Fuzzy logic aplication for sceduling ( FLASH )

FLASH pada dasarnya sama dengan CPM dalam hal activity on arrow(AOA) diagram dan perhitungannya kecuali karakteristik durasinya. Durasi aktivitas i-j dinyatakan dalam tiga nilai berbeda: batas bawah, paling mungkin, dan batas atas. Karena FLASH mengasumsikan durasi aktivitas dinyatakan dalam bilangan fuzzy segitiga, ketiga nilai tersebut merupakan nilai 1, m, dan u atau Di-j $(1, \mathrm{~m}, \mathrm{u})$. Untuk node i, Early start (Ei), dan latest start (Li) merupakan bilangan fuzzy juga tetapi tidak harus selalu bilangan fuzzy segitiga.

\section{Durasi Fuzzy Kegiatan.}

Durasi kegiatan dinyatakan datam TFN (Triangular Fuzzy Number) seperti terlihat pada gambar.

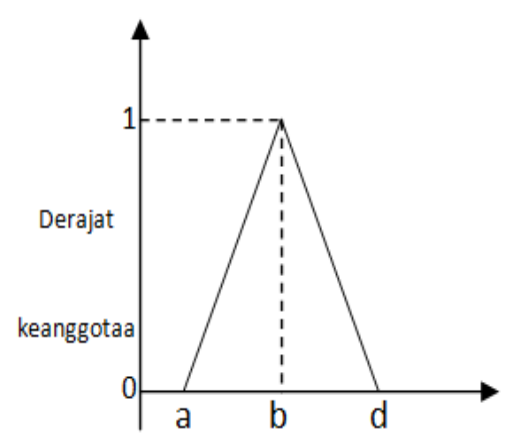

Kurva Segitiga

Nilai a dikenal sebagai durasi terpendek yang mungkin (most optimistic time), d adalah durasi paling lama (most pessimistic time) dan $b$ adalah durasi yang paling mungkin (most likely time). 
Dalam kaitannya dengan manajemen proyek, bilangan fuzzy akan dioperasikan antara lain menurut operasi - operasi sebagai berikut :

Misalnya 2 buah TFN M(a,b,c,d) dan N(e,f,g,h)

$$
\begin{aligned}
\mathrm{M}(+) \mathrm{N} & =(\mathrm{a}+\mathrm{e}, \mathrm{b}+\mathrm{f}, \mathrm{c}+\mathrm{g}, \mathrm{d}+\mathrm{h}) \\
\mathrm{M}(-) \mathrm{N} & =(\mathrm{a}-\mathrm{h}, \mathrm{b}-\mathrm{g}, \mathrm{c}-\mathrm{f}, \mathrm{d}-\mathrm{e}) \\
\operatorname{Min}(\mathrm{M}, \mathrm{N}) & =[\Lambda(\mathrm{a}, \mathrm{e}), \Lambda(\mathrm{b}, \mathrm{f}), \Lambda(\mathrm{c}, \mathrm{g}), \Lambda(\mathrm{d}, \mathrm{h})] \\
\operatorname{Max}(\mathrm{M}, \mathrm{N}) & =[\mathrm{V}(\mathrm{a}, \mathrm{e}), \mathrm{V}(\mathrm{b}, \mathrm{f}), \mathrm{V}(\mathrm{c}, \mathrm{g}), \mathrm{V}(\mathrm{d}, \mathrm{h})] \\
\operatorname{Dimana}(+) & =\text { operasi penjumplahan fuzzy } \\
(-) & =\text { oerasi pengurangan fuzzy. } \\
\mathrm{V} & =\text { maksimum. } \\
\Lambda & =\text { minimum. }
\end{aligned}
$$

Operasi maksimum dan minimum merupakan pembandingan pada tiap titik dalam dua TFN, dan keluaranya merupakan bilangan-bilangan yang sesuai dengan operatornya (maksimum /minimum). Jadi misalkan $\mathrm{A}(1,5,5,6)$ dan $\mathrm{B}(3,4,4,7)$, maka max (A,B) menghasilkan $(3,5,5,7)$.

\section{Parameter waktu kegiatan fuzzy.}

Untuk mencari jalur kritis, sebelumnya harus dicari parameter-parameter waktu dari tiap kegiatan. Parameter waktu tersebut adalah :

\section{FES ( Fuzzy Early Start)}

Waktu mulai paling awal suatu kegiatan dapatdilaksanakan

\section{FEF (Fuzzy Early Finish)}

Waktu selesai paling awal dari suatu kegiatan

$$
\text { 3. FLS (Fuzzy Late Start) }
$$

Waktu paling akhir suatu kegiatan boleh dimulai, yaitu waktu paling akhir kegiatan boleh dimulai tanpa memperlambat proyek secara keseluruhan

\section{FLF (Fuzzy Late Finish )}

Waktu paling akhir kegiatan boleh selesai tanpamemperlambat penyelesaian proyek.

\section{Perhitungan Maju}

Pencarian jalur kritis dan parameter waktu kegiatan dimulai dengan proses forward pass, yang menghitung FES dan FEF yang diawali dari awal kegiatan sampai ke akhir kegiatan. FES dan FEF dihitung dengan rumus sebagai berikut :

$$
\begin{aligned}
& \text { FESx }=\max (\text { FEFp }) \\
& \text { FEFx }=\text { FESx }(+) \text { FDx } \\
& \text { Dimana FEFx }=\text { waktu mulai tercepat dalam }
\end{aligned}
$$
fuzzy dari aktivitas $\mathrm{x}, \mathrm{p}=$ aktivitas yang mendahului, FEF $=$ waktu selesai tercepat dalam bentuk fuzzy, $\mathrm{FD}=$ durasi dari sebuah kegiatan.

\section{Perhitungan Mundur}

Proses backward pass dilakukan untuk mencari FLS dan FLF, diawali dengan kegiatan terakhir sampai dengan kegiatan awal. Backward pass dilakukan dengan perhitungan sebagai berikut :

FLS dari kegiatan terakhir dalam proyek adalah sama dengan FES-nya (kegiatan terakhir dalam proyek adalah simpul finish yang FD-nya adalah 
$(0,0,0,0))$

Kemudian dihitung PLFx $=\min ($ FLSs $)$.

Dimana PLFx $=$ waktu selesai terlama sementara, FLSs = waktu mulai terlama dari kegiatan sebelumnya (arah dari akhir proyek keawal )

PLF kemudian dikonversi menjadi FLFu (Batas atas dari waktu selesai terlama) dengan rumus :

$$
\mathrm{Au}=(\mathrm{a}, \mathrm{b}, \mathrm{c}, \mathrm{d})(-)(0,0, \infty, \infty)=(-\infty,-\infty, \mathrm{c}, \mathrm{d})
$$

Dengan FEF (a,b,c,d) dan FLFu $(-\infty,-\infty, e, f)$ dari suatu kegiatan diketahui maka akan dicari FLF dengan langkah- langkah sebagai berikut :

Mencari dari kedua angka tersebut mana yang mempunyai kemiringan ke kanan lebih besar, dengan cara membandingkan $(\mathrm{f}-\mathrm{e})$ dengan $(\mathrm{d}-\mathrm{c})$.

Menghitung Y, yaitu sebuah besaran fuzzy terbesar yang memenuhi syarat

$$
\text { FEF }(+) \mathrm{Y}<\mathrm{FLFu}
$$

Jika kemiringan ke kanan dari FEF lebih besar ( $\mathrm{d}-\mathrm{c})>(\mathrm{f}-\mathrm{e})$ atau bisa dikatakan lebih tidak pasti maka bagian kanan dari FLF dibuat sama dengan FEF. Dan $\mathrm{Y}$ didapat dari: $\mathrm{Y}=(\mathrm{f}-\mathrm{d}, \mathrm{f}-\mathrm{d}, \mathrm{f}-\mathrm{d}$, $f-d)$

Jika kemiringan ke kanan dari FLFu yang lebih besar maka bagian kanan FLF disamakan dengan FLFu namun bagian kiri disamakan dengan bagian kiri dari FEF. Maka Y adalah : Y $=(\mathrm{e}-\mathrm{c}, \mathrm{e}-\mathrm{c}$, $e-c, f-d)$

Kemudian FLF dapat dihitung dengan rumus :

$$
\mathrm{FLF}=\mathrm{FEF}(+) \mathrm{Y}
$$

Dan FLS kemudian didapat dari penurunan rumus :

$$
\mathrm{FLS}(+) \mathrm{FD}=\mathrm{F}
$$

\section{Waktu Ambang (Floats)}

Waktu ambang adalah sejumlah waktu yg tersedia dalam suatu aktifitas sehingga memungkinkan aktifitas tersebut dapat ditunda tanpa menyebabkan penambahan total durasi proyek. Ada tiga tipe waktu ambang, waktu ambang total atau total float (TF), waktu ambang bebas atau free float (FF), dan waktu ambang independen atau independent float (IF). Waktu ambang total suatu aktivitas adalah jumlah unit waktu aktivitas yang dapat diundurkan tanpa berpengaruh pada waktu penyelesaian total proyek. Waktu ambang bebas adalah jumlah unit waktu aktivitas yang dapat diundurkan tanpa berpengaruh pada ambang total aktivitas sesudahnya, sementara waktu ambang independen adalah jumlah unit waktu aktivitas yang dapat diundurkan tanpa mempengaruhi waktu ambang total dari aktivitas suksesor dan predesesor. TF, FF dan IF Pada metode fuzzy, slack dapat dihitung dengan rumus (Gin-Shuh Liang,2004) :

$$
\begin{aligned}
& \text { TFx }=\text { FLFx }- \text { FDx }- \text { FESx } \\
& \text { FFx }=\text { FESx }- \text { FDx }- \text { FEFx } \\
& \text { IFx }=\text { FESx }- \text { FDx }- \text { FLSx }
\end{aligned}
$$


kah-langkah yang ditempuh untuk memecahkan

nilai centroid. Sedangkan centroid (C) dari sebuah TFN (a,b,c,d) dapar dihitung dengan rumus ( N. Ravi Shankar,2010 ) :

$$
\mathrm{C}=(\mathrm{a}+\mathrm{b}+\mathrm{c}) / 3
$$

\section{METODOLOGI PENELITIAN}

Dalam point ini dijelaskan tentang lang- permasalahan penelitian. Tahap penelitian dimulai dari tahap identifikasi permasalahan sampai pada tahap penyelsaian, sehingga dapat diperoleh sebuah kesimpulan yang merupakan hasil ringkasan dari peneletian tersebut dan juga saran yang akan disampaikan penulis.

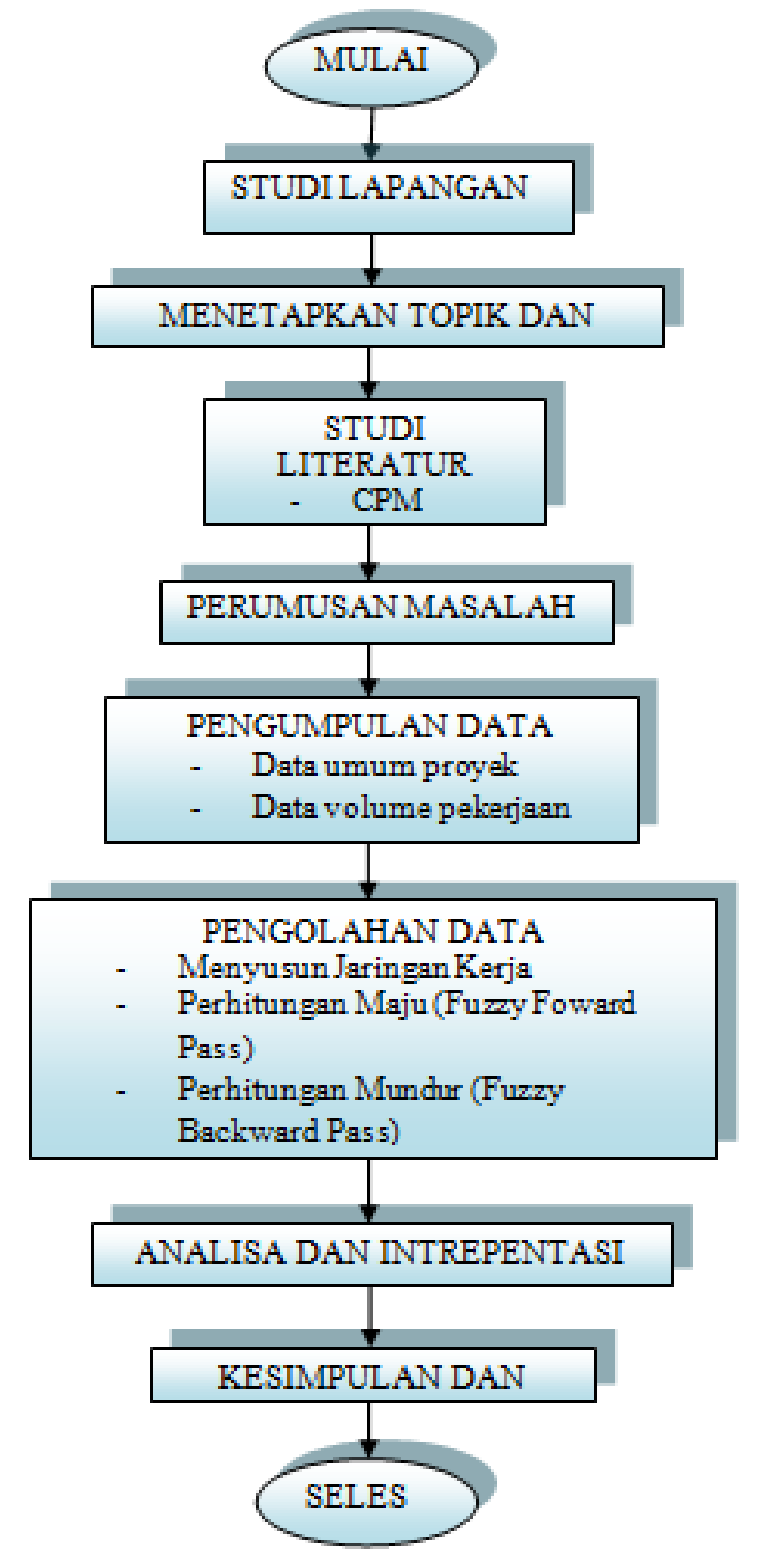

Flowchart Pemecahan masalah 


\section{PENGUMPULAN}

DAN

PENGOLAHAN

\section{DATA}

Hubungan keterkaitan pekerjaan diperoleh dari logika ketergantungan yang disebabkan oleh sifat kegiatan itu sendiri, dengan memperhatikan kegiatan apa yang dimulai terlebih dahulu (prodecessor), kegiatan apa yang mengikuti (successor) dan adakah kegiatan yang bisa dilakukan secara bersamaan / sejajar untuk menghemat waktu. Disamping itu juga hubungan antar pekerjaan memiliki keter- gantungan yang disebabkan oleh sifat kegiatan itu sendiri dikarenakan pekerjaan tersebut tidak dapat dimulai tanpa adanya input berupa hasil pengerjaan pekerjaan sebelumnya.

Durasi kegiatan dinyatakan dalam TFN (Triangular Fuzzy Number). Berikut adalah nilai waktu kendor untuk data kegiatan dan keterkaitan antar kegiatan proyek pembangunan kantor gedung PT. Gresik Jasatama :

\begin{tabular}{|c|c|c|c|c|c|}
\hline \multirow{2}{*}{ Kegatan } & \multirow{2}{*}{ Aktivitas } & \multicolumn{3}{|c|}{ Waktu fuzzy } & \multirow{2}{*}{$\begin{array}{c}\text { Kegiatan } \\
\text { pendahulu }\end{array}$} \\
\hline & & a & b & $c$ & \\
\hline A. & PEKERJAAN PENDAHULUAN & 6 & 8 & 10 & \\
\hline B. & PEKERJAAN TANAH & 12 & 18 & 23 & A \\
\hline C. & PEKERJAAN PASANGAN & 18 & 25 & 32 & B \\
\hline D. & PEKERJ IAN PLESTERAN, ACIAN DAN BENANGAN & 45 & 64 & 83 & $C M$ \\
\hline \multirow[t]{4}{*}{ E. } & PEKERJAAN BETON & & & & \\
\hline & E.1. BETON LANTA 1 & 8 & 11 & 15 & $B$ \\
\hline & E.2. BETON LANTA 2 & 5 & 8 & 11 & E1 \\
\hline & E.3. BETON ATAP LANTAI 2 & 13 & 19 & 25 & E2 \\
\hline \multirow[t]{4}{*}{ F. } & PEKERJAAN RANGKA ATAP & & & & \\
\hline & F.1. RANGKA PENUTUP ATAP LT.2 & 23 & 33 & 43 & E3 \\
\hline & F2. RANGKA ATAP KANOPI DEPAN & 1 & 2 & 3 & $\mathrm{E} 2$ \\
\hline & F3. RANGKA ATAP KANDPI SAMPING & 1 & 2 & 3 & E2 \\
\hline \multirow[t]{4}{*}{ G. } & PEKERJAAN PENUTUP ATAP DAN USPLLANK & & & & \\
\hline & G.1. PENUTUP ATQ LANTA 2 & 6 & 8 & 10 & $\mathrm{~F} 1$ \\
\hline & 6.2. PENUTUP ATA KANOPI DEPAN & 1 & 2 & 3 & $\mathrm{~F} 1, \mathrm{~F} 2$ \\
\hline & 6.3. PENUTUP ATA KANOPI SAMPING & 1 & 2 & 3 & $\mathrm{~F} 1, \mathrm{~F} 2$ \\
\hline H. & PEKER.JAN LANTAI & 19 & 28 & 36 & G1 \\
\hline I. & PEKERJAAN PLAFOND & 4 & 6 & 8 & G1 \\
\hline ل. & PEKERJAAN PENGECATAN & 17 & 24 & 31 & $D, 1, K 1, K 2,1,1,2$ \\
\hline \multirow[t]{3}{*}{ K. } & PEKERJAAN NUSEN PINTU DAN JENDELA & & & & \\
\hline & K.1. PINTU DAN JENDELA LANTA 1 & 12 & 17 & 23 & E2 \\
\hline & K.2. PINTU DAN JENDELA LANTA 2 & 13 & 18 & 23 & E3 \\
\hline \multirow[t]{3}{*}{ L. } & PEKERJAAN PARTISI & & & & \\
\hline & L.1. PARTISI LANTA 1 & 5 & 7 & 8 & H \\
\hline & L.2. PARTISI LANTAI 2 & 3 & 5 & 7 & $H$ \\
\hline M & PEKERJAAN SANTARR & 15 & 21 & 28 & B \\
\hline N. & PEKEKRIAAN MEKAN KAL DAN LECTRICAL & 5 & 7 & 9 & $\mathrm{~N}$ \\
\hline
\end{tabular}




\section{Jaringan kerja (diagram network)}

Untuk membentuk suatu diagram jaringan kerja dengan metode CPM maka dibutuhkan hubungan ketergantungan antar pekerjaan yang satu dengan pekerjaan lainnya dimana hubungan pekerjaan tersebut merupakan kendala (constraints) yang dapat mempengaruhi kemampuan sumber daya untuk melaksanakan proyek. Dalam kasus proyek pembangunan gedung kantor PT. Gresik Jasatama, ada beberapa penjadwalan kegiatan pada pekerjaan tipikal ditempatkan tumpang tindih, beberapa diantaranya adalah pada pekerjaan beton yang belum selesai $100 \%$ sudah harus dimulai dengan pekerjaan pasangan, hal ini akan memperngaruhi dalam penyusunan jaringan kerja.

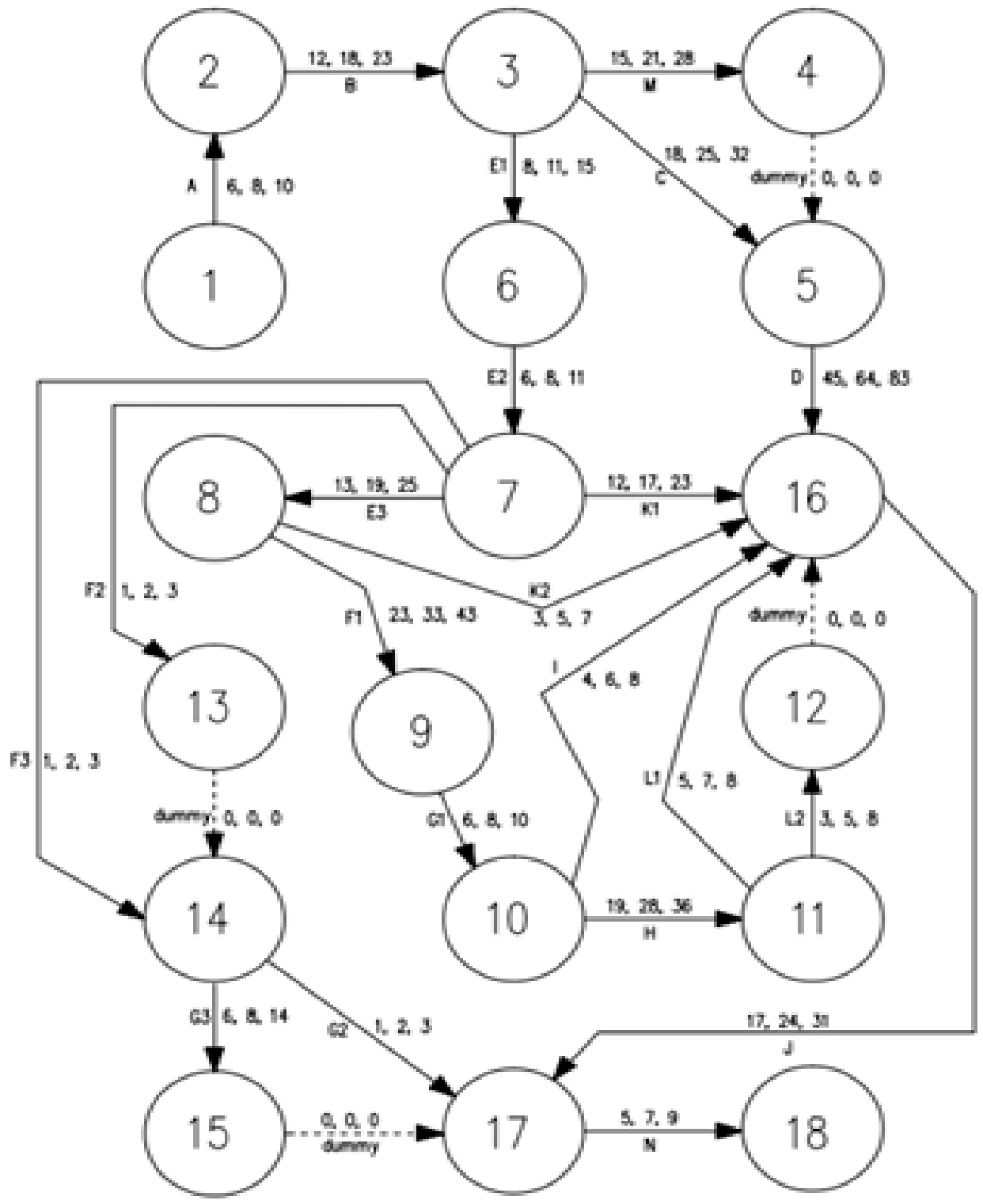




\section{Penggunaan waktu fuzzy tiap aktivitas.}

Untuk mencari jalur kritis, sebelumnya harus dicari parameter-parameter waktu dari tiap kegiatan. Parameter waktu tersebut adalah :

\section{FES ( Fuzzy Early Start)}

Waktu mulai paling awal suatu kegiatan dapat dilaksanakan

\section{FEF (Fuzzy Early Finish)}

Waktu selesai paling awal dari suatu kegiatan

\section{FLS (Fuzzy Late Start)}

Waktu paling akhir suatu kegiatan boleh dimulai, yaitu waktu paling akhir kegiatan boleh dimulai tanpa memperlambat proyek secara keseluruhan

\section{FLF (Fuzzy Late Finish )}

Waktu paling akhir kegiatan boleh selesai tanpamemperlambat penyelesaian proyek.

\section{Fuzzy Forward Pass (Perhitungan maju).}

Perhitungan maju adalah perhitungan yang dimulai dari node start (awal) dan bergerak ke end (akhir) untuk menghitung Fuzzy Early Start (FES) dan Fuzzy Early Finish (FEF).

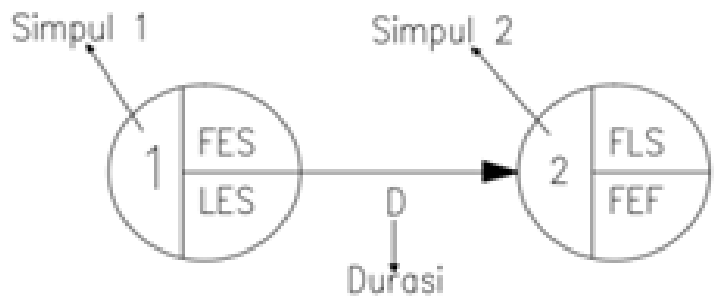

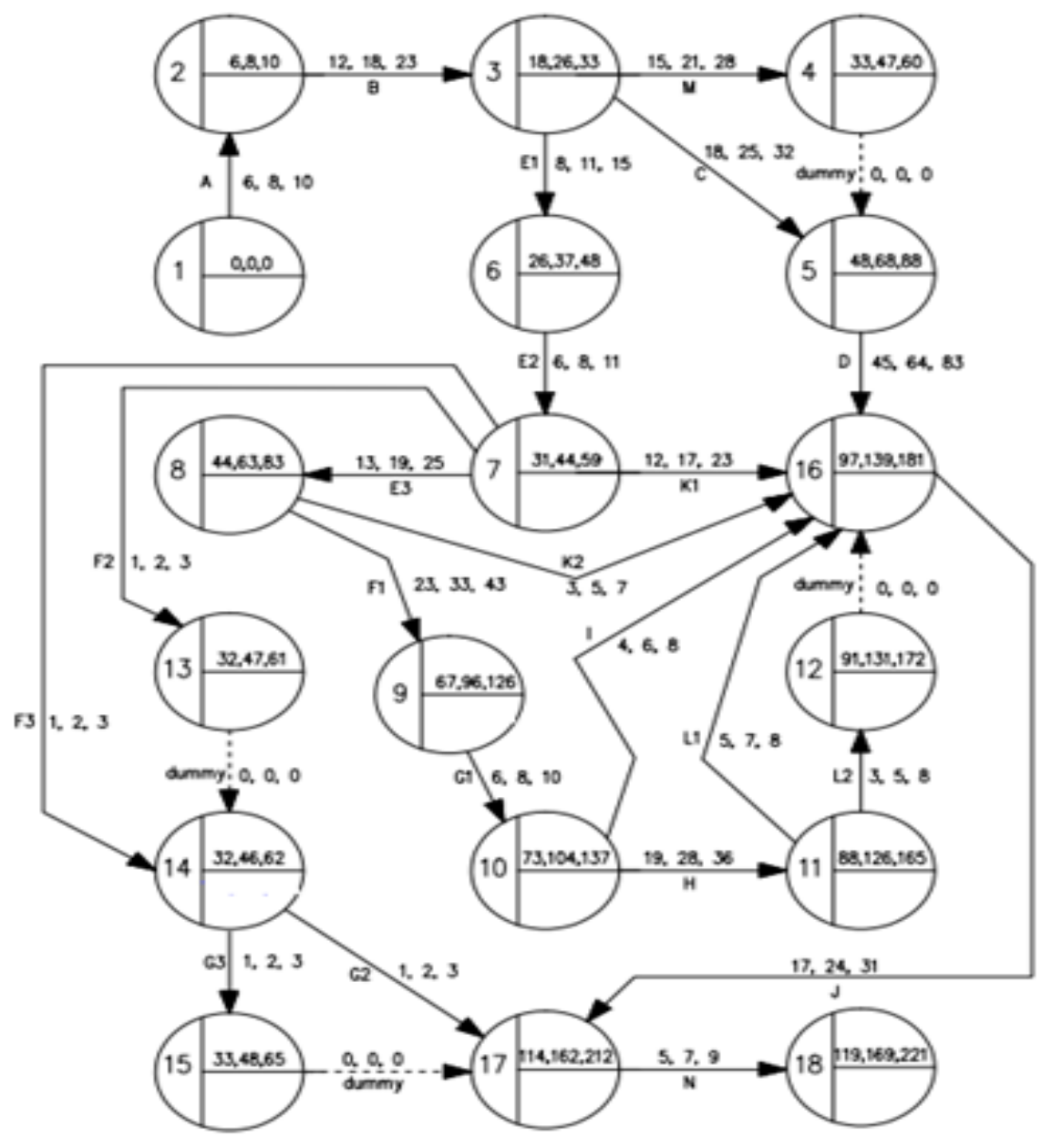


Dari jaringan kerja diatas dapat dilakukan perhitungan maju sebagai mana

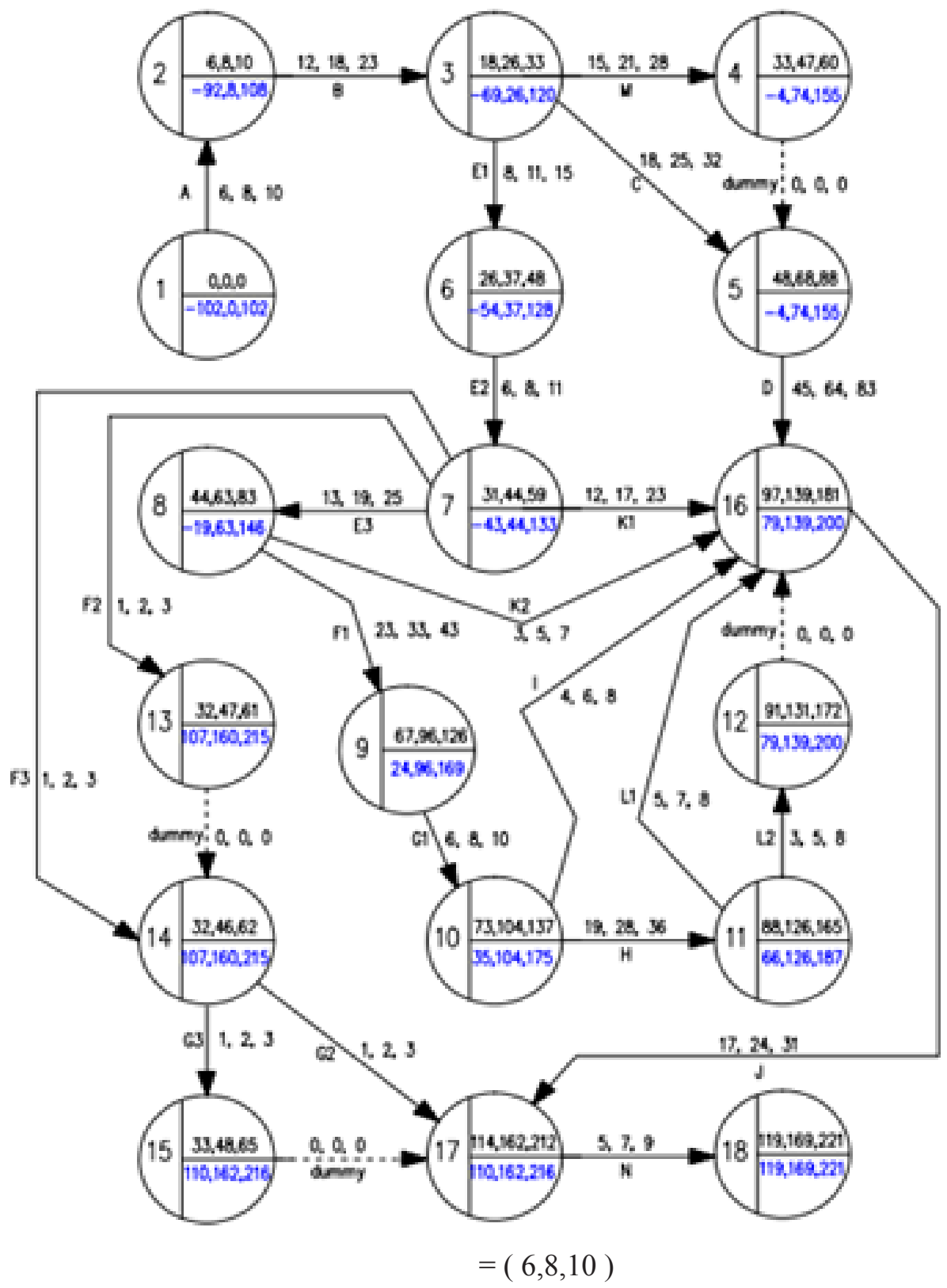

$$
\begin{aligned}
& \text { FESx }=\max (\text { FEFp }) \\
& \text { FEFx }=\text { FESx }(+) \text { FDx }
\end{aligned}
$$

Bila FESa $=0$ (waktu mulai proyek), FESb dapat dihitung yaitu

$$
\begin{aligned}
\mathrm{FESb} & =\mathrm{FESa}+\mathrm{FDa} . \\
& =(0,0,0)+(6,8,10) \\
& =(0+6,0+8,0+10)
\end{aligned}
$$

Dengan cara yang sama FESc, FESe1, FESe2, FESe3, FESf1, FESf2,FESg1, FESh, FESi, FESk1, FESk2, FES11, FES12, dan FESm dapat dihitung. Karena kegiatan pendahulu D lebih dari satu kegiatan maka FESd dapat dicari dengan cara membandingkan kegiatan pendahulu tersebut, mana kegiatan yang memiliki nilai paling maksimum. 


$$
\begin{aligned}
\mathrm{C} & =(18,26,33)+(18,25,32) \\
& =(36,51,65) \\
\mathrm{M} & =(18,26,33)+(15,21,28) \\
& =(33,47,61)
\end{aligned}
$$

$\operatorname{Max}(\mathrm{A}, \mathrm{B})=\mathrm{V}[(36,33) \mathrm{V}(51,47) \mathrm{V}(65,61)]$

$=(36,51,65)$

$$
\text { Jadi FESd }=(36,51,65)
$$

\begin{tabular}{|c|c|c|c|c|c|c|c|c|c|c|c|c|}
\hline \multirow{2}{*}{ gegatan } & \multirow{2}{*}{ Honta } & \multicolumn{4}{|c|}{ Dara } & \multirow{2}{*}{$\begin{array}{l}\text { leggan } \\
\text { patanudu }\end{array}$} & \multicolumn{3}{|c|}{$\overline{\text { F }}$} & \multicolumn{3}{|c|}{ FG } \\
\hline & & $a$ & 0 & c & $\mathrm{c}$ & & a & 0 & c & a & 0 & c \\
\hline a & POERLAN POCAHLUAN & 6 & 8 & 10] & 8 & & 0 & 0 & 0 & 6 & 8 & 10 \\
\hline 8. & PgerLaNTAMH & & 18 & 23 & 18 & A & 6 & 8 & 10 & 18 & $\mathrm{z}$ & 33 \\
\hline$c$ & PERERLAN PASIGAN & & $\mathrm{z}$ & 32 & $\mathrm{~s}$ & 6 & 18 & 26 & 33 & 8 & 68 & 88 \\
\hline 0. & PEKRLAN P.STER, KAN & $\theta$ & 64 & 83 & 64 & CM & 83 & 68 & 88 & 97 & 139 & 18: \\
\hline \multirow[t]{4}{*}{ E. } & POERLAN BTON & & & & & & & & & & & \\
\hline & E1. BETONLANA1 & 8 & 11 & 15 & 11 & 6 & 18 & 26 & 33 & 26 & 37 & 8. \\
\hline & E2. BETONLATH2 & 5 & 8 & 11 & 8 & $\theta$ & 26 & 37 & s. & 31 & 4 & 59 \\
\hline & E3. BGONATP UNTA2 & & 19 & 5 & 19 & E & 31 & 4 & 59 & 4 & 63 & 83 \\
\hline \multirow[t]{4}{*}{ f. } & POKERLAN RA GKA AAP & & & & & & & & & & & \\
\hline & F1. REGLA PENTIP ATR LTI & 23 & 33 & B) & 33 & 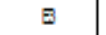 & 4 & 63 & 83 & 67 & 96 & 128 \\
\hline & 2. RWGKATREKA & & 2 & 3 & 2 & E] & 31 & 4 & 59 & 32 & 16 & 62 \\
\hline & :3. RWGLATR KAOA SUMANG & 1 & 2 & 3 & 2 & El & 31 & 4 & 59 & 32 & 16 & 62 \\
\hline \multirow[t]{4}{*}{$G}$. & 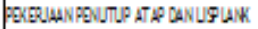 & & & & & & & & & & & \\
\hline & 3.1. PEUTUP ATR U & 6 & 8 & 10 & 8 & P & 67 & 96 & tos & 73 & & 137. \\
\hline & 22. PQUTUP ATP KANOIOCPWN & 1 & 2 & 3 & 2 & ค,, 2 & 32 & 16 & 62 & 114 & 162 & 21 \\
\hline & 6.3. PQUTIP ATPK & 1 & 2 & 3 & 2 & ค., 7 & 32 & 15 & 62 & 114 & 162 & 21 \\
\hline H & PGERLANLWTII & & $x$ & 36 & 28 & G & 73 & 04 & 37 & 92 & 132 & 178 \\
\hline L & POGRLAN PLPONO & 4 & 6 & 8 & 6 & G & 73 & 04 & 37 & 97 & 139 & 180 \\
\hline 1. & PGERUAN POGGATAN & & 24 & 31 & 24 & $0,10, K, 1,1,2$ & 97 & 69 & 81 & 114 & & $21:$ \\
\hline \multirow[t]{3}{*}{ k. } & 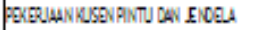 & & & & & & & & & & & \\
\hline & 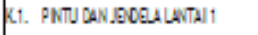 & & 17 & 23 & 17 & E & 31 & 4 & 59 & 97 & & 18 \\
\hline & 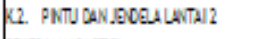 & & 18 & & 18 & B & 4 & 63 & 83 & 97 & & 18: \\
\hline \multirow[t]{3}{*}{ L. } & 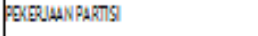 & & & & & & & & & & & \\
\hline & -1. PRTQuir, & ? & 7 & 8 & 7 & $H$ & 92 & 92 & TI & 97 & 139 & 18 \\
\hline & -2. PARTQUNTI2 & & 5 & 7 & 5 & $H$ & 92 & 13 & 173 & 97 & 139 & 180 \\
\hline N. & PESRLANSENTAR & & 21 & 28 & 21 & 8 & 18 & $2 \mathrm{~s}$ & 33 & 8 & 63 & 88 \\
\hline$\underline{\mathbb{N}}$ & 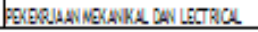 & 5 & 7 & 9 & 7 & $\mathrm{~N}$ & 114 & 82 & & 119 & & \\
\hline
\end{tabular}

Dengan cara yang sama FESd, FESj, FESg2,

FESg3 dan FESn dapat dihitung, Berikut adalah hasil perhitungan maju :

\section{Fuzzy Backward Pass (Perhitungan mundur).}

Perhitungan mundur dilakukan untuk mencari menghitung Fuzzy Late Start (FLS) dan Fuzzy late Finish (FEF). Perhitungan dimulai dari kegiatan paling terakhir sampai dengan kegiatan awal.

Dari jaringan kerja diatas dapat dilakukan per- hitungan maju sebagai mana berikut:

$$
\begin{aligned}
& \text { FLFx }=\min (\text { FLSp }) . \\
& \text { FLSx }=\text { FLFx (-) FDx. }
\end{aligned}
$$

FLS dari kegiatan terakir proyek adalah sama dengan FES-nya, sehingga FD-nya adalah $(0,0,0)$. FLSm dapat dihitung yaitu :

$$
\begin{aligned}
& \text { FLSm }=\text { FLFm }- \text { FDm } . \\
& \quad=(114,163,213)-(5,7,9) \\
& =(114-9,163-7,213-5) \\
& =(105,156,208)
\end{aligned}
$$

Dengan cara yang sama FLSj, FLSd, FLSg12, FLSe2, FLSb1, dan FLSa2, dapat dihitung. Karena FLS11, FLS12 diawali oleh kegiatan yang sama, maka FLS11, FLS12, dapat dicari dengan cara membandingkan kegiatan yang mengawali L1 dan L2 kegiatan mana yang memiliki nilai paling minimum.

$$
\begin{aligned}
\mathrm{L} 1 & =(79,139,200)(5,7,8) \\
& =(79-8,139-7,200-5) \\
& =(71,132,195) \\
\mathrm{L} 2 & =(79,139,200)(3,5,7) \\
& =(79-7,139-5,200-3) \\
& =(72,134,197)
\end{aligned}
$$

$\operatorname{Min}(\mathrm{A}, \mathrm{B})=[\Lambda(71,72) \Lambda(132,134) \Lambda($ 195,197 ) ]

$$
=(71,132,195)
$$

$$
\text { Jadi FESd }=(71,132,195)
$$

Dengan cara yang sama juga (FLSfl dan 
FLSk2), (FLSg2, FLSg3, (FLSc, FLSe1, dan FLSm) dan ( FLSk1, FLSe3, FLSf2 dan, FLSf3) dibandingkan dan dicari nilai minimum sebagai FLS masing-masing kegiatan tersebut. Berikut adalah hasil perhitungan mundur :

\begin{tabular}{|c|c|c|c|c|c|c|c|c|c|c|c|}
\hline \multirow{2}{*}{ ititus } & \multicolumn{4}{|c|}{ Durat } & \multirow{2}{*}{$\begin{array}{l}\text { Keģatal } \\
\text { Extàdu }\end{array}$} & \multicolumn{3}{|c|}{ P.S } & \multicolumn{3}{|c|}{ PF } \\
\hline & a & 0 & $c$ & $c$ & & a & 0 & $c$ & $a$ & 0 & 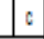 \\
\hline 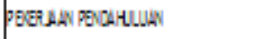 & 6 & 81 & 0 & 8 & & -102 & 0 & 102 & 42 & & \\
\hline PoçAN TANAH & 21 & 182 & 23 & 18 & A & -92 & 8 & 108 & 69 & & \\
\hline POCHLN PISLGLN & 82 & 253 & 32 & 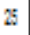 & 8 & 60 & 26 & 120 & 4 & & \\
\hline 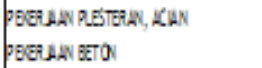 & 56 & 648 & 83 & 64 & CM & -4 & 74 & 195 & $\theta$ & & \\
\hline 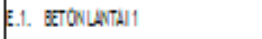 & 81 & 111 & 15 & 11 & 8 & $\theta 9$ & 26 & 120 & 64 & & \\
\hline :1. gETOLLATI2? & 5 & 81 & 11 & 8 & E1 & -54 & 37 & 128 & 4 & & \\
\hline 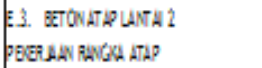 & $13+$ & 192 & 25 & 19 & E2 & -43 & 4 & 133 & 49 & 63 & \\
\hline 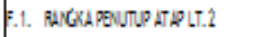 & 33 & 33 & a & 33 & es & -19 & $\mathrm{~B}$ & 156 & 2 & 9 & \\
\hline 2. RUGCLATR KLOPIOEPW & 12 & 2 & 3 & 2 & E2 & -4 & 4 & 133 & 107 & & \\
\hline 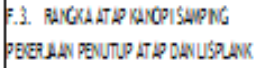 & 12 & 23 & 3 & 2 & 9 & -6 & 4 & 133 & 107 & & \\
\hline 4.1. mentupitipurin? & 6 & 81 & 10 & 8 & Fi & 24 & 9 & 160 & $\mathbf{z}$ & & \\
\hline 2.1. PEUTIPITIRK & 12 & 2 & 3 & 2 & 91,72 & 107 & 160 & 215 & 110 & & \\
\hline 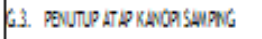 & 12 & 2 & 3 & 2 & $p 1,12$ & 107 & 160 & 215 & 110 & & \\
\hline PอсR LiN LATTH & 192 & 28 & 8 & 8 & G & 35 & 104 & 175 & $\pi$ & & \\
\hline PอCนAN RUFONO & 4 & 6 & 8 & 6 & G1 & 35 & 104 & 175 & $\theta$ & & 92 \\
\hline PEGuav pectataN & $\pi 2$ & 243 & & 24 & $0,1, K 1, K 2,1,1,2$ & 9 & 139 & 200 & 110 & & \\
\hline 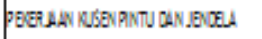 & & & & & & & & & & & \\
\hline 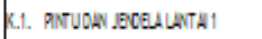 & 21 & 172 & 23 & 17 & E2 & -6 & 4 & 133 & $\theta$ & & 9 \\
\hline 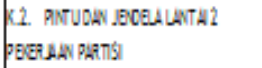 & 131 & 182 & 23 & 18 & E & -19 & 63 & 155 & $\theta$ & & 9 \\
\hline -1. Partisurka1 & 5 & 7 & 8 & 7 & $H$ & $\pi$ & 132 & 195 & $\theta$ & & \\
\hline 1. partisuntar & 3 & 5 & 7 & 5 & H & 9 & 132 & 173 & $\Phi$ & & 7 \\
\hline POCHAN SUNTAR & 152 & & 8 & 21 & 8 & 69 & $z$ & 120 & 4 & & 41 \\
\hline 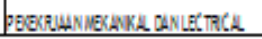 & 5 & 7 & 9 & 7 & N & 110 & 162 & & & & \\
\hline
\end{tabular}

Perhitungan Slack (Waktu ambang).

Ada tiga tipe waktu ambang yaiti waktu ambang total total float (TF),waktu ambang bebas atau free floats $(\mathrm{FF})$, dan weaktu ambang independen (IF) . Pada metode fuzzy, slack dapat dihitung dengan rumus (Gin-Shuh Liang,2004) :

$$
\begin{aligned}
& \text { TFx }=\text { FLFx }- \text { FDx }- \text { FESx } \\
& \text { FFx }=\text { FEFx }- \text { FDx }- \text { FESx } \\
& 1 F x=\text { FEFx }- \text { FDx }- \text { FLSx }
\end{aligned}
$$

Dimana notasi $\mathrm{x}$ menunjukan suatu kegiatan, dan $\mathrm{C}=$ nilai centroid.

Sedangkan nilai centroid (C) dari sebuah TFN $(a, b, c)$ dapat dihitung dengan rumus (N. Ravi Shankar,2010) :

$$
\begin{aligned}
\mathrm{C} & =(\mathrm{a}+\mathrm{b}+\mathrm{c}) / 3 \\
\mathrm{TFa} & =\mathrm{FLFa}-\mathrm{Fda}-\mathrm{FESa} \\
& =(-92,8,108)-(6,8,10)-(0,0,0) \\
& =(92-10-0)-(8-8-0)-(10 \\
& =(-102,0,102)
\end{aligned}
$$

Sehingga nilai centroidnya $(C)=(-102+0+$ $102) / 3=0$

$$
\begin{aligned}
\mathrm{FFa} & =\mathrm{FEFa}-\mathrm{Fda}-\mathrm{FESa} \\
& =(6,8,10)-(6,8,10)-(0,0,0) \\
& =(6-10-0)-(8-8-0)-(10-6-0) \\
& =(-4,0,4)
\end{aligned}
$$
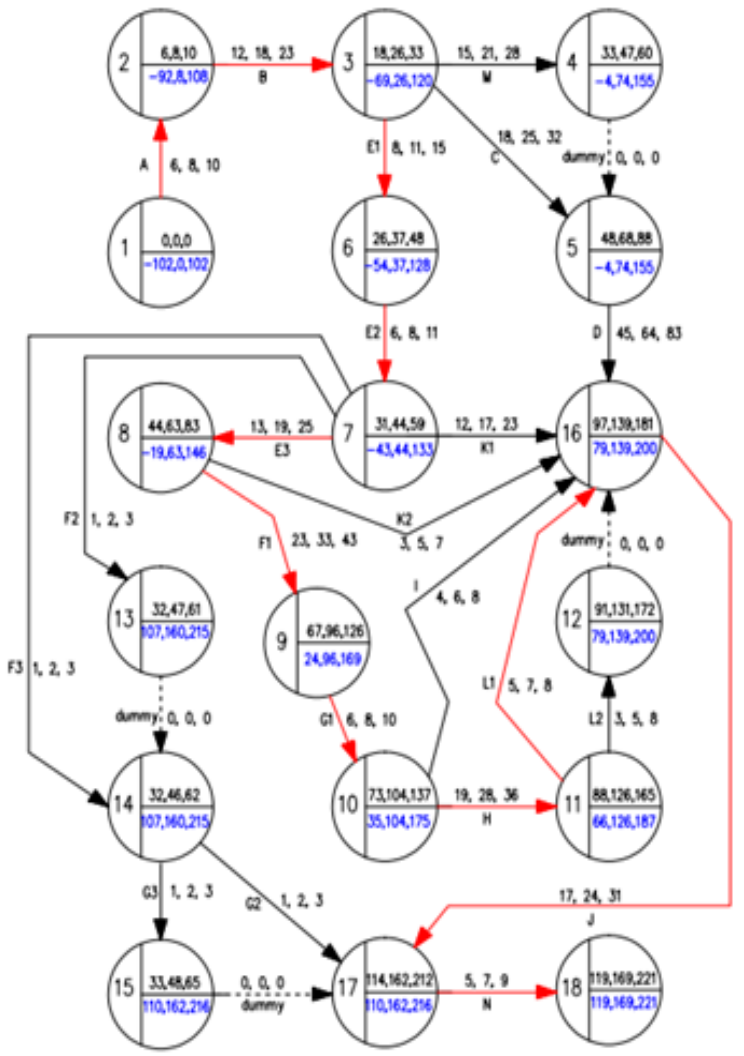
Sehingga nilai centroidnya $(\mathrm{C})=(-4+0+$ $4) / 3=0$

Dengan cara yang sama total float (TF), free float (FF) dan independen float ( IF) dapat dihitung. Berikut adalah hasil perhitungan TF, FF, dan IF dari masing-masing kegiatan :

\begin{tabular}{|c|c|c|c|c|c|c|c|c|c|c|c|c|}
\hline \multirow{2}{*}{ kegitan } & \multirow{2}{*}{ Hentso } & \multicolumn{4}{|c|}{ TF } & \multicolumn{4}{|c|}{ F } & \multicolumn{3}{|c|}{ F } \\
\hline & & a & 0 & $\mathrm{c}$ & c & a & 0 & c & $c$ & a & 0 & c \\
\hline A & 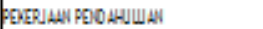 & 402 & 0 & 102 & 0 & -4 & 0 & 4 & 0 & 406 & 0 & 106 \\
\hline B. & 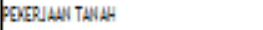 & 702 & 0 & 102 & 0 & -15 & 0 & 15 & 0 & $=13$ & 0 & 113 \\
\hline c & FOERU LUI PLSAIGLA & $-\pi$ & 23 & 19 & 24 & $-x$ & 0 & 20 & 0 & $=16$ & 0 & 116 \\
\hline o. & POER AW PLETEALI, LOAN & $-\pi$ & 23 & 19 & 24 & -5 & 23 & 100 & 24 & $\div 10$ & 0 & 100 \\
\hline \multirow[t]{4}{*}{ E } & FGER AN в:TON & & & & & & & & & & & \\
\hline & 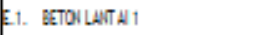 & -102 & 0 & 10 & 0 & $-n$ & 0 & 22 & 0 & $\neq 10$ & 0 & 110 \\
\hline & E2. แTOLLITL2 & 402 & 0 & 102 & 0 & -8 & 0 & 28 & 0 & $=108$ & 0 & 108 \\
\hline & 13. EETOI LTAPLATIN 2 & -102 & 0 & 10 & 0 & $-x$ & 0 & 39 & 0 & :14 & 0 & 114 \\
\hline \multirow[t]{4}{*}{ F. } & 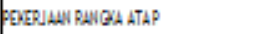 & 0 & 0 & 0 & 0 & 0 & 0 & 0 & 0 & 0 & 0 & 0 \\
\hline & 1. PAVGLA PEUTUP ATRP IT.2 & 402 & 0 & 10 & 0 & -9 & 0 & 99 & 0 & $\neq 22$ & 0 & 122 \\
\hline & 1. PWIGKA ATLP KAOPI DCPNI & 5 & $\pi 4$ & 104 & $\pi 4$ & $-\infty$ & -1 & 30 & 0 & =104 & A & 105 \\
\hline & 1. PALGKA ATP KNOPI SAIFING & 6 & $\pi 4$ & $1 \mathfrak{m}$ & $\pi 4$ & -30 & 0 & 30 & 0 & -105 & 0 & 104 \\
\hline \multirow[t]{4}{*}{ G } & FOER AW FEUTUP ATA P OA UFLUNK & & & & & & & & & & & \\
\hline & E.1. PEUTUP LTLP LNTA I & $=02$ & 0 & 102 & 0 & $-a$ & 0 & 64 & 0 & $=07$ & 0 & 107 \\
\hline & 5.2. PEUTUP ATRP KAOPI LCPNI & 5 & $\pi 4$ & $1 \widetilde{m}$ & $\pi 4$ & $\theta$ & $\pi 4$ & $\pi$ & $\pi 4$ & $=104$ & 0 & 104 \\
\hline & 2.3. PEUTUP ATLP KLOPI SIIFING & 5 & $\pi 4$ & 18 & $\pi 4$ & $\theta$ & $\pi 4$ & $\pi$ & $\pi 4$ & $=104$ & 0 & 104 \\
\hline H. & Foger LAN LATAI & -102 & 0 & 102 & 0 & $-\infty$ & 0 & 80 & 0 & $: 19$ & 0 & 119 \\
\hline L & POERUAN PLLOND & -6 & 28 & 12 & 28 & -8 & 28 & 04 & 28 & - $x$ & 28 & 142 \\
\hline 1. & FOERUAU POVGECATAN & 402 & 0 & 102 & 0 & $-x$ & 0 & 98 & 0 & $=16$ & 0 & 116 \\
\hline \multirow[t]{3}{*}{ k. } & FOER AU NUEN PITU DAN DOEL & & & & & & & & & & & \\
\hline & 1. PMT U DW JECELA LNITN 1 & -2 & $\pi$ & 15 & $\pi$ & 8 & $\pi$ & 138 & $\pi$ & -9 & $\pi$ & 213 \\
\hline & 2.2. PITU DWIOCELALWTA 2 & -8 & 57 & 18 & 57 & -9 & 57 & 24 & 57 & $-\pi$ & 57 & 187 \\
\hline \multirow[t]{3}{*}{ L } & FOERLAI PART BI & & & & & & & & & & & \\
\hline & -1. PARTISLATL 1 & -102 & 0 & 108 & 0 & -4 & 0 & 84 & 0 & 406 & 0 & 106 \\
\hline & 12. PHRTILLTA2 & 2 & 0 & 10 & 7 & $n$ & 2 & 86 & 2 & -2 & 2 & $\approx$ \\
\hline a. & POERUAISALTAR & $-a$ & $2 \pi$ & 12 & 28 & -2 & 4 & 32 & 4 & $\{12$ & 4 & 119 \\
\hline k & 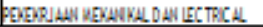 & -102 & 0 & 10 & 0 & 40 & 0 & 102 & 0 & & 0 & 106 \\
\hline
\end{tabular}

\section{Menentukan Lintasan Kritis.}

Lintasan kritis merupakan lintasan pada aktifitas kegiatan yang tidak boleh terjadi keterlambatan, apabila terjadi keterlambatan maka umur proyek akan bertambah sebesar keterlamnatan tersebut. Kegiatan ini adalah kegiatan yang memiliki slack atau total float (TF) 0 ,sehingga kegiatan ini harus memperoleh perhatian khusus, dari pengolahan data diatas dapat digambarkan alur lintasan kerja sebagai berikut :

\begin{tabular}{|c|c|}
\hline LNASAN & SLACK \\
\hline A.B.M.D.I.N & $0.0 .28 \cdot 24 \cdot 0.0$ \\
\hline A.B.C.D.I.N & $0.0 \cdot 24 \cdot 24 \cdot 0 \cdot 0$ \\
\hline$A \cdot B \cdot E 1 \cdot E 2-E 3 \cdot G 3 \cdot N$ & $0 \cdot 0 \cdot 0 \cdot 0 \cdot 114 \cdot 114 \cdot 0$ \\
\hline$A \cdot B \cdot E 1 \cdot E 2 \cdot E_{3} \cdot G_{2} \cdot N$ & $0 \cdot 0 \cdot 0 \cdot 0 \cdot 114 \cdot 114 \cdot 0$ \\
\hline$A \cdot B \cdot E 1 \cdot E 2 \cdot F 2 \cdot G \cdot N$ & $0 \cdot 0 \cdot 0 \cdot 0 \cdot 114 \cdot 114 \cdot 0$ \\
\hline$A \cdot B \cdot E 1 \cdot E 2 \cdot E 2 \cdot G 2 \cdot N$ & $0 \cdot 0 \cdot 0 \cdot 0 \cdot 114 \cdot 114 \cdot 0$ \\
\hline$A \cdot B \cdot E 1 \cdot E 2 \cdot K 1 \cdot J \cdot N$ & $0.0 \cdot 0 \cdot 0 \cdot 77 \cdot 0.0$ \\
\hline $\mathrm{A} \cdot \mathrm{B} \cdot \mathrm{E} 1 \cdot \mathrm{E} 2 \cdot \mathrm{E} \cdot \mathrm{K} 2 \cdot \mathrm{J} \cdot \mathrm{N}$ & $0.0 \cdot 0 \cdot 0 \cdot 0.52 \cdot 0 \cdot 0$ \\
\hline$A \cdot B \cdot E 1 \cdot E 2 \cdot E 3 \cdot F 1 \cdot G 1 \cdot I \cdot J \cdot N$ & $0 \cdot 0 \cdot 0 \cdot 0 \cdot 0 \cdot 0 \cdot 0 \cdot 28 \cdot 0 \cdot 0$ \\
\hline$A \cdot B \cdot E 1-E 2-E B-F 1-G 1-H \cdot L 1-J \cdot N$ & $0.0 \cdot 0 \cdot 0 \cdot 0 \cdot 0 \cdot 0 \cdot 0 \cdot 0.0$ \\
\hline A.B.E1-E2-E3-F1-G1-H.L2-J.N & $0 \cdot 0 \cdot 0 \cdot 0 \cdot 0 \cdot 0 \cdot 0 \cdot 7 \cdot 0 \cdot 0$ \\
\hline
\end{tabular}

\section{KESIMPULAN}

Dari hasil pengolahan data dan analisis yang sudah dilakukan dapat ditarik kesimpulan sebagai berikut:

1. Pada jaringan kerja Proyek pembangunan kantor PT. Gresik Jasatama diperoleh 11 lintasan.

2. Dari hasil perhitungan dengan menggunakan metode Fuzzy Logic Application for Scheduling(FLASH), menunjukan waktu penyeleseian proyek berada pada kisaran 119 hari sampai dengan 221 hari dengan waktu paling mungkin 163 hari dengan nilai defuzzyfikasi 170 hari.

3. Pada proyek pembangunan gedung kantor PT. Gresik Jasatama kegiatan yang tidak boleh mengalami keterlambatan adalah pekerjaan persiapan, pekerjaan tanah, pekerjaan plesteran acian dan benangan, pekerjaan beton lantai 1, pekerjaan beton lantai 2, pekerjaan atap lantai 2, pekerjaan penutup atap lantai 2, pekerjaan penutup atap kanopi samping, pekerjaan lantai, pekerjaan pengecatan, 
pekerjaan partisi lantai 2, dan pekerjaan elektrical dan mechanical.

\section{DAFTAR PUSTAKA}

Badri, S. 1997. "Dasar-dasar Network Planing”. Jakarta : PT Rika Cipta.

Clifford F. Gray, Erik W. Larson, (2007), Manajemen Proyek Proses Manajerial, Edisi 3, ANDI, Yogyakarta.

Efendi, Moch. 2012. “Analisa Jaringan Kerja Proyek pembuatan Gudang Kavling Q Di Lokasi PT. Kawasan Industri Gresik Dengan Metode Pert

Dan Fuzzy”. Gresik: SKRIPSI.

Dannyanty, Eka. “ Optimalisasi Pelaksanaan Proyek dengan Metode Pert dan Cpm”. Eprint. Undip.ac.id. Diakses 26 mei 2014.

Hamzah. M H, El Unas. Saefoe dan Widiarsa. “ Penjadwalan Proyek konstuksi dengan metode Flash (Fuzzy Logic Aplication For Scheduling)”. www.google.com. Diakses 25 mei 2014

Handoko, T.H.. 1999. "Dasar-dasar Manajemen Produksi Dan Operas"i, Edisi Pertama. BPFE : Yogyakarta.

Hayun, Anggara. 2005. "Perencanaan dan Pengendalian Proyek dengan Metode PERT-CPM : Studi Kasus Fly Over Ahmad Yani, Karawang.” Journal The Winners, Vol. 6, No.2, h. 155-174.
Heizer, Jay dan Barry Render. 2005. Operations Management : Manajemen Operasi. Jakarta : Salemba Empat.

Kusumadewi, Sri. 2004. “ Aplikasi Logika fuzzy Untuk Pendukung Keputusan”. Yogyakarta: Graha Ilmu.

Levin, Richard I. dan Charles A Kirkpatrick. 1972. "Perentjanaan dan Pengawasan Dengan PERT dan CPM". Jakarta : Bhratara

Maharany, Leny dan Fajarwati. 2006. "Analisis Optimasi Percepatan Durasi Proyek dengan Metode Least Cost Analysis." Utilitas, Vol. 14, No. 1, h. 113-130.

N. Ravi Shankar, V. Shireesa and P. Phani Bhusan Rao.2010," An Analytical Method For Finding Critical Path in a Fuzzy Project Network". India Departement of Applied Mathematics GIS.

Santosa, Budi. 2009. "Manajemen Proyek". Surabaya: Graha ilmu. 